\title{
ESBOÇO DE CUMPLICIDADE
}

\author{
* Maria Arminda do Nascimento Arruda
}

Sou capaz de me lembrar da primeira vez que vi a então professora Eni Samara, depois minha amiga e colaboradora. Apesar das diferenças de situação, ambas parecíamos viver uma condição semelhante. Eu era uma jovem socióloga, casada com um historiador eminente, e Eni era uma jovem professora do Departamento de História da Universidade de São Paulo, instituição que eu conhecia desde o fim da minha adolescência. Encontramo-nos na casa da professora Anita Novinski, historiadora celebrada por seus estudos sobre a Inquisição no Brasil, além de ser uma senhora viva, de aparência marcante, talhada para o papel de excelente anfitriã. Eni e eu estávamos presentes nas reuniões e nos jantares oferecidos pela elegante hostess. Eu, na condição de mulher e acompanhante do marido; ela, passando pelo rito de ser admitida na confraria. Ambas neófitas nos nossos papéis. Sintomaticamente, eu procurava me integrar na conversa dos convidados, para mim nem sempre atraente. Sentia certo deslocamento, explícito na dificuldade de aceitar, não o ambiente elegante, mas a concordância com posições comumente vistas, por mim, como ultrapassadas. Naquele momento, eu não conseguia conviver com certa concepção difundida, sobretudo em meio a uma comunidade de corte mais tradicional, que manifestava uma visão mais hierárquica e de feitio cristalizado da vida acadêmica. Aquelas ocasiões, percebidas, hoje, em perspectiva, me levam a pensar que algo se passava, de modo semelhante, com Eni.

Se a minha manifestação de estranhamento poderia ser atribuída ao fato de eu não pertencer ao ambiente dos historiadores, como explicar a impressão que a historiadora me criava? Como entender o fato de que ela ficava, por vezes, afastada do burburinho da conversa, fumando isoladamente o seu cigarro, mas sempre acompanhada da sua sogra? Havia algo de deslocado nessa figura: a primeira imagem emitia um sinal de mulher independente, elegante, distante e até um tanto blasé; a segunda, lembrava uma pessoa conservadora, a mais tradicional possível para o tempo, já que transcorriam os anos I980: o da mulher que não se apresentaria publicamente sem um companheiro e, na sua ausência, sem a garantia representada pela figura da sogra, avalista do seu estado civil, cônscia dos deveres familiares. Eni, no entanto, expunha outros vestígios negadores de aquiescência aos valores do passado.

Mulher elegante, de uma elegância evidente, já que cuidadosamente construída para acentuar a sua condição, a historiadora se vestia em concordância com os símbolos aderidos às expressões mais atuais da distinção social, expressando uma espécie de disposição para se diferenciar, relevante, sobretudo, em um contexto, muito ascético em relação às manifestações mais flagrantes de status. Eni Samara não era, aos meus olhos, uma pessoa simples e a sua complexidade estava exposta na sua imagem. Eu, tampouco, deveria exprimir uma figura pacificada, uma vez que mal conseguia equilibrar-me em meio a tantas contradições que, diga-se passagem, pareciam ser percebidas pela dona da casa, presentes nos seus comportamentos de gentileza voltados ao bem-estar dos convidados.

Alguns anos se passaram. Encontrei-me com Eni, novamente, em um seminário promovido pela Faculdade de Ciências Econômicas da Universidade Federal de Minas Gerais, no final do decênio, quando eu tentava me firmar na vida profissional, realizando o meu doutoramento e Eni, já portadora do título, apresentava o resultado das suas pesquisas no campo da Demografia

* Professora titular junto do Departamento de Sociologia da Faculdade de Filosofia, Letras e Ciências Humanas (FFLCH) da Universidade de São Paulo e Pró-Reitora de Cultura e Extensão Universitária da USP. 
Histórica, mas já se encaminhando para as pesquisas sobre gênero que distinguiriam os seus estudos posteriores. Tivemos uma convivência harmoniosa naquele cenário romântico de Diamantina; ameno, porém, as duas pareciam ter consciência de estarem imersas em um ambiente que nem sempre as compreendia. Com o recuo do tempo, tenho, hoje, a sensação de que Eni e eu fomos de certa maneira outsiders na vida acadêmica, não no seu sentido substantivo, daquele que significa encontrar na vida intelectual a sua principal atração, atração que, inúmeras vezes, pareciam ausentes por causa da figura que parecíamos representar. Algo de diverso havia, por certo, entre nós. Eni era mais especializada do que eu, reproduzindo a marca da vivência que tivera nas universidades americanas, o que não deixava de provocar estranheza de minha parte. Tínhamos, todavia, uma concordância de fundo, lastreada num tipo de sociabilidade que preservava certos padrões fixados de etiqueta. Eu gostava disso e, penso, que o nosso relacionamento futuro desenvolveu-se na esteira de tal afinidade.

Um outro momento de convivência mais próximo com Eni aconteceu em um seminário realizado pela Universidade Lusíada, no Porto, já durante o decênio de I990. Foram bons dias. Saímos juntas, fomos a museus, apreciamos a moda - mais ela do que eu - caminhamos pela cidade. Não me encontrava bem, ainda perseguida pelo falecimento do meu jovem irmão, evento que me ocupava integralmente e deixava um lastro de pânico nas minhas apresentações. O meu desempenho foi sofrível; percebi que ela compreendeu. Naqueles dias vislumbrei outra pessoa: esmerava-se ainda mais na aparência, denotando esforço para cuidar de si; havia se transformado numa pesquisadora dedicada à História de Gênero, em especial, às mulheres brasileiras na Época Colonial. Ocorria, novamente, uma espécie de disjunção entre a adesão a um tema identificado com a liberação e a imagem construída por ela. Naqueles dias, perguntei-me com qual figura ficar, qual era, no fundo, a identidade de Eni, mesmo reconhecendo as minhas próprias dificuldades de transmitir uma visão mais coerente da minha personalidade. A já minha amiga rompia expectativas assentadas. Em outra ocasião, novamente em Portugal, apresentei um trabalho sobre a trajetória do meu avô açoriano que aportou no Brasil no final do século XIX, considerado, no debate, um esforço bem sucedido de análise social de biografias. A minha colega das terras lusitanas apreciou o estudo e convidou-me par apresentá-lo para seus orientandos no CEDHAL.

Desde então, selamos uma espécie de pacto, isto é, de companheiras de um caminho assemelhado e pertencente a uma estirpe de mulheres acadêmicas que portavam, contraditoriamente, uma dupla face: aparentemente tradicionais em certas condutas; mas anunciadoras de um novo tempo, daquele em que se reconhece o direito à diversidade. Imbuídas de tal reconhecimento, ainda que de modo não explícito e mesmo não consciente, apoiamo-nos nas ocasiões em que ambas pretenderam ascender na carreira acadêmica. Possivelmente, por isso, construímos uma espécie de cumplicidade. Se Eni me provocava alguma perplexidade, vejo, agora, que era o espelho do meu próprio estar no mundo, de uma condição de presença afastada, não ausente, mas tampouco totalmente identificada ao ambiente, uma modalidade de experiência de estar à margem. Raramente podemos acordar combinações não explícitas, nascidas do reconhecimento de afinidades que não necessitam de formulações evidentes. Esse era o nosso caso; assim construímos o nosso relacionamento.

Mesmo quando me disse do retorno da sua doença, ela sabia da minha contrariedade, mas tinha segurança da minha solidariedade, sem que nenhuma palavra tivesse sido dita, além daquelas protocolares em ocasiões dessa ordem. Sinto, agora, o quanto nossas afinidades eram reais. Eni, na sua aparência composta, até cuidadosamente construída, que passava uma imagem de estar bem com as circunstâncias, era, no fundo, uma mulher na qual se percebia uma melancolia dançando no seu olhar. Não haveria naquele olhar vestígio de algo desejado e não realizado? 